\title{
What Determines Tax Incentives and How Effective Are They?
}

\author{
Åsa Hansson* \\ Lund University \\ Research Institute of Industrial Economics \\ Sweden \\ Susan Porter \\ McIntire School of Commerce \\ University of Virginia \\ Susan Perry Williams \\ McIntire School of Commerce \\ University of Virginia
}

\begin{abstract}
This paper considers factors determining tax incentives and examines how effective they are using data from OCED and EU countries. It is well known that countries compete when it comes to setting the statutory corporate tax rate but do they also compete when it comes to providing tax incentives on the tax base side? The paper starts out by analyzing factors affecting different tax incentive measures and then moves on to analyze how effective different incentives are in attracting investments. We study several different tax incentives and find them to be ineffective in generating investments and, that, reductions of statutory corporate tax rates are a more efficient way to generate investments.
\end{abstract}

Keywords: Tax incentives, tax competition, policy uncertainty

JEL Classification:H25, H32, L38

\section{Introduction}

International competition between countries in attracting investments is fierce and increasing. It is by now well known that countries compete by lowering corporate statutory tax rates in order to gain foreign investments and to entice firms to locate within a country's jurisdiction. There is a sizeable literature documenting that corporate tax rate competition takes place (see e.g., Devereux et al., 2008, Wilson, 1999, Wilson \&Wildasin, 2004, Wildasin 1988). However, countries can attract investments and gain firm locations by offering tax breaks through specific tax incentives as well. For instance, countries that are constrained to lower statutory tax rates by their political structure can use tax incentives to lower the tax burden in order to attract investments and firm establishments (Hansson et al., 2015). Or countries can complement low statutory rates by also providing generous tax incentives to make the tax regime even more competitive. While there is sizeable research on the determinants and effects of tax rate competition there is little research on the impact of tax incentives. This study extends the literature by examining what factors impact the decision to offer incentives and analyzes whether tax incentives affect foreign direct investments (FDI) and gross fixed capital formation.

Even though economists in general believe that tax incentives are less effective in attracting investments than lower statutory tax rates (e.g., Klemm, 2010\& van Parys, 2012) there may still be reasons to provide tax incentives. For example, Keen (2001), claims that tax incentives make tax competition less harmful as they allow lower tax rates on the more mobile tax bases while preserving higher rates for less mobile tax bases. In addition, countries may face political pressure to, at least, appear to impose significant tax burdens on businesses (Hines 2017), and as reductions in the tax base are less noticeable than reducing the statutory tax rate it may be politically easier to do the former.

*Corresponding author, address: Department of Economics, Lund University, Box 7082, S-220 07 Lund, Sweden, e-mail:asa.hansson@nek.lu.se,phone: +46-709-584889. 
Common tax incentives provided within OECD countries include incentives to stimulate R\&D (e.g., patent boxes and $R \& D$ credits), activities in certain economic zones in order to boost employment and investments, incentives for investment in firm start-ups and small businesses, and accelerated depreciation. The EU Code of Conduct and strict regulations concerning State Aid make it difficult to engage in tax competition and limit tax credits to certain sectors. Despite this constraint, many EU countries provide tax incentives in order to compete. As it becomes increasingly difficult to lower tax rates it is likely that other means will appear - even though these may be a less efficient means to gain investments. Lately, patent boxes (a specific tax incentive for intellectual property) have been implemented in several countries, but are by many seen as an aggressive form of tax competition.

The purpose of this study is twofold. First, to explore what factors determine tax incentives in OECD countries and whether countries with high statutory tax rates compensate by offering more generous incentives,or whether attractive rates go hand in hand with offering generous tax incentives. In addition, we ask whether countries take tax incentives offered in other countries into account when setting their own, that is, whether there are interdependency in determining tax incentives as well as statutory tax rates. Our second purpose isto analyze what impact aggregate as well as specific tax incentives have on FDI inflows and gross fixed capital formation.

The knowledge of factors determining tax incentives and whether countries also act strategically when it comes to providing tax incentives is scarce. While there is a large empirical literature on tax rate determinants there is very little empirical research on factors determining tax incentives. This is not surprising given that it is hard to measure tax incentives. The current study tries to fill this void by using three different measures of tax incentives in order to get a comprehensive understanding of factors determining tax incentives within OECD countries. First, we construct an inclusive measure of tax incentives measuring the deviation between the revenues due if the entire tax base was taxed at statutory tax rates and the average actual tax payments (based on tax revenues received). This measure includes all deviations from the statutory rate including interest deductions, depreciations, allowances, credits, along with targeted incentives such as industry specific incentives and enterprise zones. This is also our preferred measure of tax incentives. Second, we follow Klemm (2010) and measure tax incentives as the difference between the statutory tax rate and the effective marginal tax rate (as calculated by Devereux et al., 2002). This measure is based on the tax costs of capital on a hypothetical marginal investment project and rests on a number of assumption about capital structure and type of investment. This measure captures some, but not all, of the incentives offered throughout the business community for each country and is, hence, more narrow than our preferred measure. Third, we construct a discrete measure counting the actual tax incentives provided by a country based on that country's tax law including tax accounting choices, investment incentives, financing costs and miscellaneous business taxes.

To further explore the impact of incentives, we move on to analyze how these aggregate as well as specific tax incentives affect inflows of FDI and gross fixed capital formation. Specifically, we look at some commonly provided specific tax incentives such as incentives for $R \& D$, small firm creation, and enterprise zones, as well as depreciation and loss offset rules, and how these affect FDI inflows and gross fixed capital formation, respectively.

We find some interesting results. For instance, we find that countries that have higher statutory tax rates tend to offer more incentives. Hence, we find that tax incentives seem to be used to compensate for high statutory rates rather than complementing and providing a more attractive tax regime. We do not find any support indicating that incentives are interdependent between jurisdictions. However, we do find that the level of institutional constraints put on the legislative power is positively correlated with level of incentives, which suggests that incentives may be offered in lieu of lowering statutory rates in jurisdictions with a high level of institutional constraints. Offering tax incentives is not an effective method for attracting investments; tax incentives do not appear to affect either inflows of FDI or gross fixed capital formation significantly. Policy and tax uncertainty, on the other hand, seems to impact investments negatively.

The paper is organized as follow. The next section gives a short overview of the empirical literature on tax incentives and factors determining them. Section three describes and discusses our measures of tax incentives and how they have developed over time. In section four we estimate factors influencing tax incentives and section five discusses the results. In section six we study the impact tax incentives have on investments and finally, section seven concludes the paper. 


\section{Previous literature}

Compared to the literature on determinants of corporate tax rates and the competition that arises across countries when setting tax rates, the literature on tax incentives is scarce. However, there are several studies that look at the effectiveness of specific tax incentives, for instance R\&D tax credits (Bloom et al., 2002, Brokelind \& Hansson, 2014), patent boxes (Alstadsaeter et al., 2018) or enterprise zones (Bondonio \& Greenbaum, 2007 and OECD, 2001) and their effect on R\&D spending and economic activity, respectively. While Hansson \& Brokelind (2014) find little support for a positive effect of $R \& D$ incentives on investment and economic performance, Bloom et al. (2002) find evidence that tax incentives are effective in increasing R\&D intensity in a sample of nine OECD countries. It is not clear, however, whether the increased R\&D intensity has a positive effect on the economy as a whole. Results suggest that reclassification of expenditures towards $R \& D$ may occur when $R \& D$ incentives are granted. Alstadsaeter et al. (2018) find that patent boxes have a significant effect on attracting patents, mostly due to their favorable tax treatment effect. They also find that patents with high earnings potential are particular sensitive to patent taxation, and that patent boxes with a large coverage tend to have stronger effects on the location of patents. Positive effects of enterprise zones seem to be limited. Studies comparing economic zones with neighboring regions without incentives find very small benefits on employment and investments, mainly because the incentives distort competition between new and old businesses.

An important consideration is, hence, whether these incentives result in benefits that outweigh the costs in a general equilibrium setting. To answer that question is difficult. In general, the literature is skeptical about the effectiveness of tax incentives. For example, Janeba\& Peters (1999) show that a total ban on tax policies that differentiate between two tax bases raises the equilibrium level of tax revenues in all countries. Van Parys (2012) find that corporate tax incentives in developing countries are successful in attracting more incentives but fail to be beneficial overall (Brys et al., 2016). However, Keen (2001) argues and illustrates that targeted reduced tax rates for the most mobile activities may be a rational response to tax competition. If not all capital is equally mobile, targeted reductions may reduce the negative effects of tax competition and increase tax revenues. Janeba \& Smart (2003) show that in a general model of tax competition over mobile tax bases limited tax incentives are harmful when the global capital stock is fixed, but may be beneficial if the total capital stock increases with lower tax rates and tax incentives. Moreover, Gugl \& Zodrow (2006) consider the welfare effects of granting tax incentives on more mobile capital, and using simulations under reasonable assumptions find that providing incentives to mobile capital can be beneficial.

More generally, the question concerns whether to follow the principal of optimal taxation, where each tax base is taxed according to its elasticity, or the principal of uniform taxation, where different tax bases are taxed uniformly to avoid distortions. In general, the principal of uniformity is proposed and favored but tax competition and globalization may shift in favor of the principal of optimality. If statutory tax rates are harder to adjust, tax base incentives can be granted as an alternative in order to provide lower effective taxation on the more mobile tax bases. However, a concern offering tax incentives is that it may open up for specia 1 interest groups to lobby for tax incentives, increasing the incentives offered and leading to overall inefficiencies.

We find little research on the effectiveness of tax incentives, and even less on factors determining tax incentives in developed countries. Klemm \& Van Parys (2012) analyze factors influencing tax incentives and whether tax incentives are used as tools of tax competition in less-developed countries (LDCs). More specifically, they look at whether there is strategic interaction in corporate tax rates and such incentives as tax holidays and investment tax credits that are commonly provided in LDCs. They find evidence for strategic interaction when it comes to corporate tax rates and tax holidays but not for investment credits. The also find that lower corporate tax rates and longer tax holidays attract FDI in Latin America and the Caribbean. Moreover, James (2009) analyzes how investment incentives affect private investment, for developing countries, and finds that the investment climate is an important factor in attracting investment. There may be reasons to suspect that the effects may differ in more develop countries. Jensen (2013), for example, finds that the level of taxation and amount of incentives offered depend on the level of democracy in a country. By using firm-level data to determine difference in taxes paid in democratic versus authoritarian regimes he finds that democratic regimes limit their offering of incentives and more effectively police tax avoidance, and as a result raise 26 percent more tax revenue than in authoritarian regimes. 
To summarize, there are no overwhelmingly strong results pointing to tax incentives being effective in generating overall positive effects. Instead, the literature is far from conclusive and motivates further investigation. Our study differs from prior research in several important ways. First, we look at broader measures of tax incentives that provide for a more aggregate analysis. Second, we study the determinants for a number of rich EU/OECDcountries where tax rates and tax competition is a greater strategic decision. Third, we include not only economic variables but also a wide set of political variables that are likely to influence tax rate and tax incentives offered. Forth, we also study how effective tax incentives are in attracting and generating investments.

\section{Measuring Tax Incentives}

As already mentioned, statutory tax rates give a poor measure of effective tax burden as tax base rules are neglected. The effective tax burden can be lowered by offering generous tax base deductions and tax credits. There is a sizable literature showing that tax base rules, such as depreciation rules, tax credits, and incentives, are as important determinants for effective tax rates as are statutory tax rates (see e.g., Lee \& Swenson, 2012). There also seems to be a sizable variation in the gap between statutory and effective rates across EU countries, and these differences in tax base rules can act as means to attract investments (Lee \& Swenson, 2012).

It is not straightforward how to define and measure these tax reliefs or tax incentives provided by the tax code. To combat this problem we use three different measures of tax incentives. One based on differences in revenues that would have been collected had all profits faced the statutory rate and actual revenues collected (REVINCENT). A second based on differences in statutory and effective marginal tax rates (ETRINCENT). A third based on hand collected incentives offered (HANDINCENT).The firstand preferred measure, REVINCENT, we derive constitutes a broad measure that captures the deviations between a firm's corporate taxes based on the statutory rate on all corporate profits (regardless of capital structure) and taxes actually paid. That is, the tax relief, $T R$, and the corresponding tax incentive, $T I$, given equal

$T R_{i t}=S T R_{i t} \pi_{i t}-$ taxrev $_{i t}$, and

$T I_{i t}=T R_{i t} / \pi_{i t}=S T R_{i t}-$ taxrev $_{i t} / \pi_{i t}$

where, $T I_{i t}$ is tax incentive given in countryi at time $t$ as a share of profit; $S T R_{i t}$ is the statutory tax rate in country $i$ attime $t ; \pi_{i t}$ is corporate profit (measured as operating surplus); and taxrev $_{i t}$ is the actual tax revenues paid on corporate profits. To calculate aggregate tax incentives across OECD countries according to this measure we use gross operating surplus data from National Income Account data as a proxy for corporate profits and tax revenue data from National Income Account Data for the measure of actual tax revenue on corporate profits. ${ }^{1}$ Figure 1 illustrates the development of this measure from 1979 to 2010 for an OECD- and EU-sample, respectively. The trend is declining. This could possibly be explained by the tax-base broadening tax-rate cutting reforms that took place during the period. As this measure is inclusive, it is quite large in magnitude, but is on a downward trend (on average a cut by 50 percent). It is interesting to note that while the value of the tax relief on the base side has declined, countries continue to offer and consider new base-reduction reforms to motivate desired economic behavior.

Figure 1. The development of tax incentives measured as REAVINCENT, 1979-2010

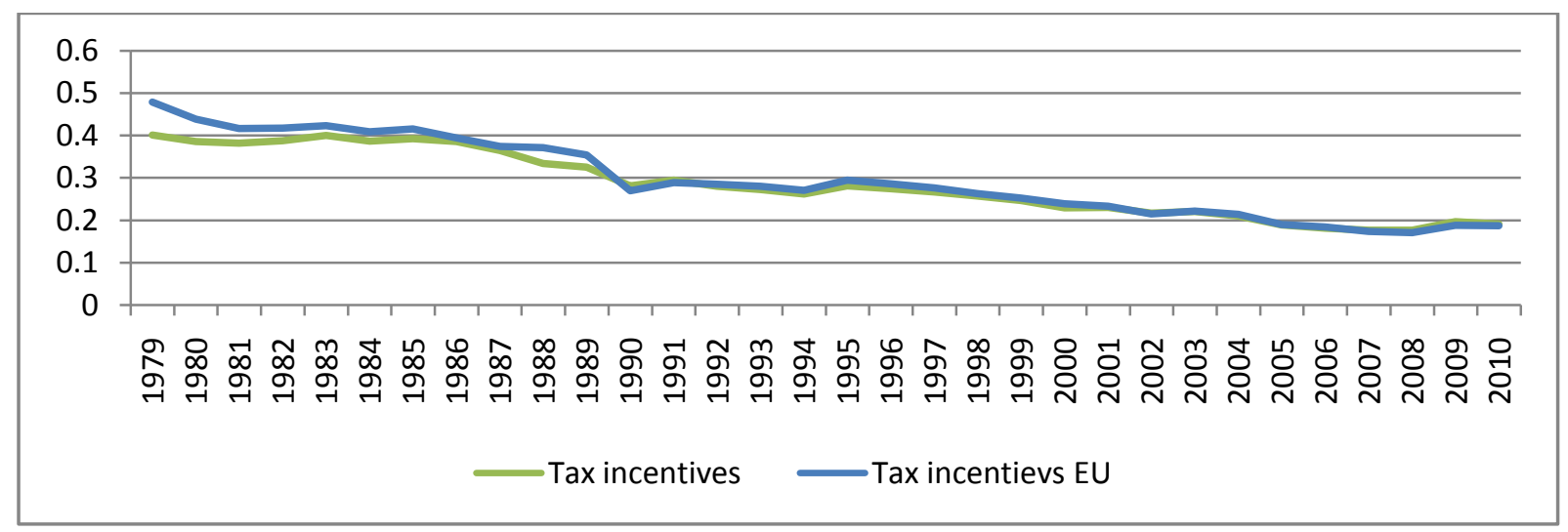

\footnotetext{
${ }^{1}$ This measure is similar to average effective tax rates calculated by Mendoza et al. (1994). Their measure of capital taxation measures the tax burden on the individual level, while our measures the average tax burden in the corporate sector. 126
} 
The second measure, ETRINCENT, estimates incentives as the difference between the statutory tax rate and the marginal effective tax rates calculated based on a hypothetical investment project. ${ }^{2}$ This measure is less inclusive and depends on a number of assumptions about capital structure and nature of investment. This method has been used by Klemm (2010), where he defines tax incentives as “ ... all measures that provide explicitly for a more favorable tax treatment of certain activities or sectors compared to what is granted to general industry" (Klemm, 2010, p. 315).

Figure 2. The development of tax incentives measured as ETRINCENT, 1979-2005

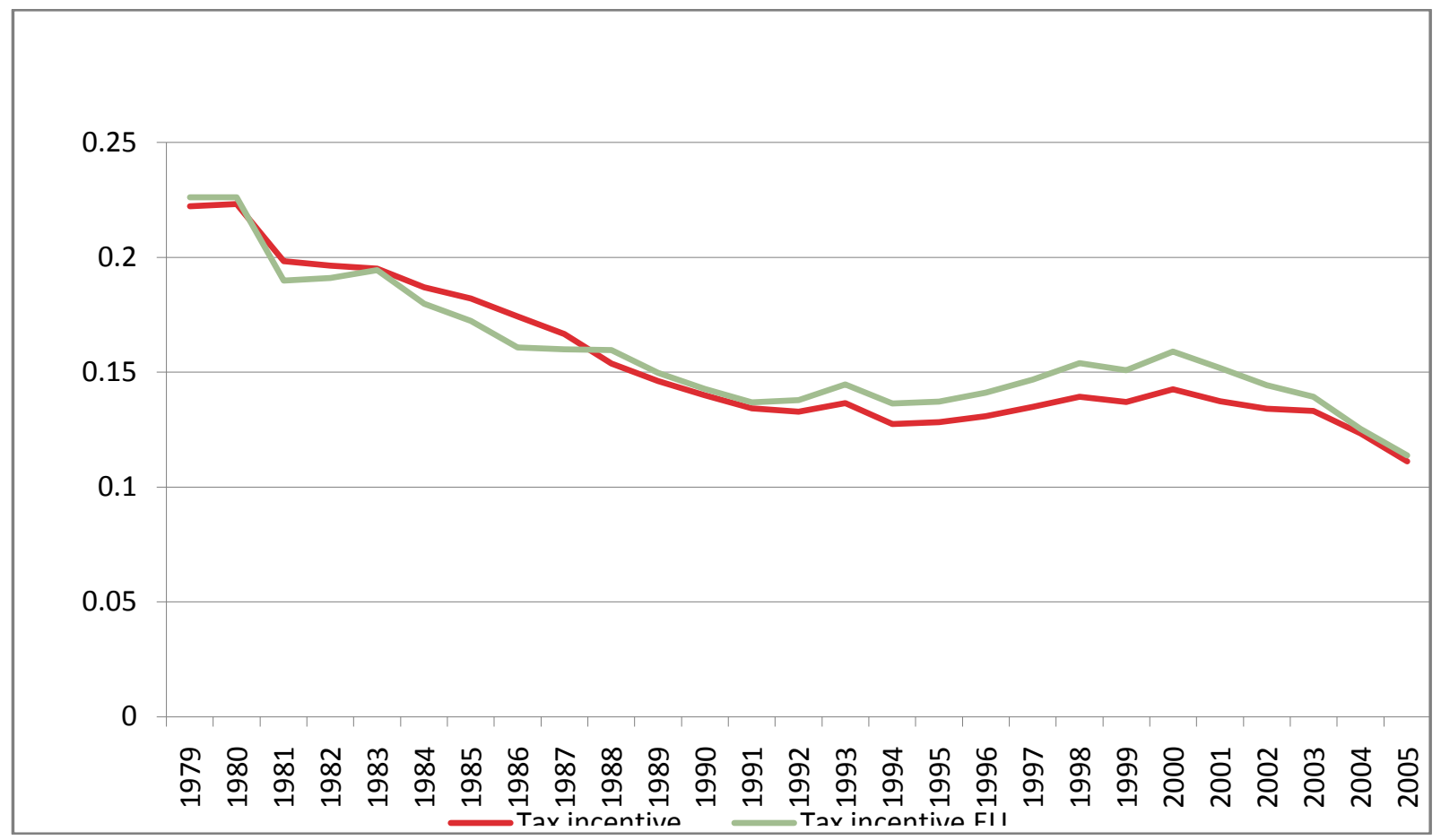

Figure 2 shows the development of this tax incentive measure from 1979 to 2010 for an OECD- and EU-sample, respectively. The development of this measure also shows a declining trend for both sets of country groups, also possibly due to the tax-base broadening tax-rate-cut reforms undertaken in many countries during this time period. On average, this incentive has declined from 22 percent in the early 1980s to 11 percent in 2005. Interestingly, since the late 1980s tax incentives offered in the EU are slightly more generous than in the OECDsample.

Our third measure of tax incentives, HANDINCENT, is based on enacted tax laws that are collected using handcollected tax law data from 1990 to 2010 for 18 European countries. Information used is provided by International Bureau of Fiscal Documentation (IBFD). This measure includes a wide range of tax incentives based on tax base inclusions. Specifically, included are depreciation rules, valuation of inventories, loss-offsetting rules, accounting for contingencies, like-kind exchanges, incentives provided for $R \& D$, small firm creation, enterprise, transfer pricing, and the number of tax treaties. Based on these rules we have constructed an index that ranges, across the EU countries, from 2-19, where a larger number indicates more generous total tax incentives. This index measures the number of incentives and also to some extent the value of them as a larger number is given for incentives that are more generous in amount such as investment and $R \& D$ tax credits. For instance, loss carry forward is taking on a value of 0,1 , and 2 with two representing the most generous rules allowing the use of losses. The intent of this measure is not to determine the governmental expenditures on incentives, rather it is measuring the number of incentives that are being offered by EU countries to determine how frequently they are being used in tax policy. The development of this index is shown in figure 3.

\footnotetext{
${ }^{2}$ The marginal effective tax rate is determined by the cost of capital and depends on a number of assumptions, e.g., depreciation rules and whether the investment is financed by equity or debt.
} 
Figure 3. The development of tax incentives based on actual tax laws (HANDINCENT), 1990-2010

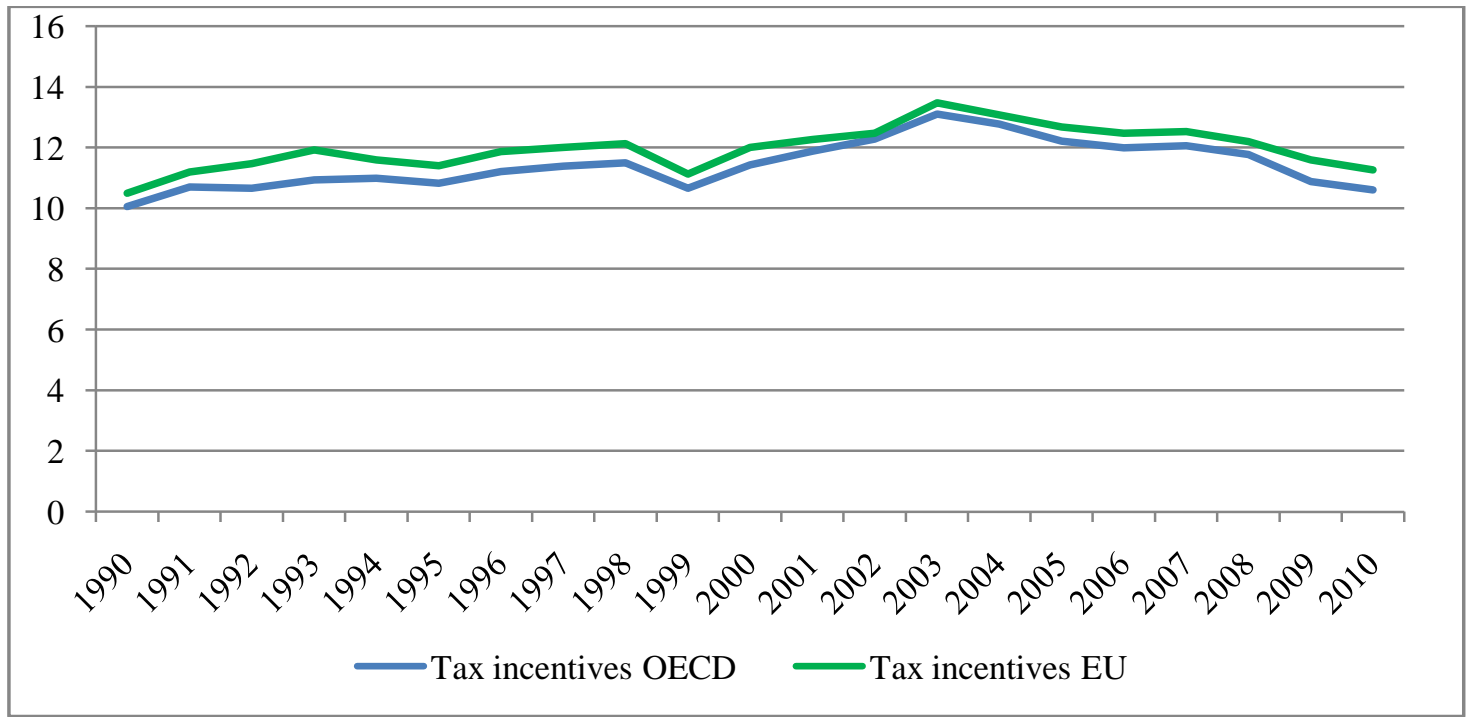

Tax incentives based on this approach show a somewhat different pattern. The number of incentives available in European countries has increased slowly; with the number of incentives offered reaching its peak in 2003. Again, this measure is slightly higher in the EU-sample than the OECD-sample for the whole time period. The different patterns for the three measures suggests that the number of incentives offered may have increased and that they are more targeted, but that the width and magnitude of them have declined.

One hypothesis is that countries facing high statutory tax rates compensate for this by offering more and/or more generous incentives. Another hypothesis is that countries with attractive statutory corporate tax rates complement this with generous tax incentives in order to provide an overall attractive tax regime. There is a strong positive correlation between the statutory corporate tax rate and two of our tax incentive measures; REVINCENT (0.89) and ETRINCENT (0.59). The correlations between the statutory tax rate and HANDINCENT and between HANDINCENT and ETRINCENT and REAVINCENT, respectively, are negative, however.

Figure 4. Statutory tax rates, marginal effective tax rates and tax incentives (HANDINCENT)

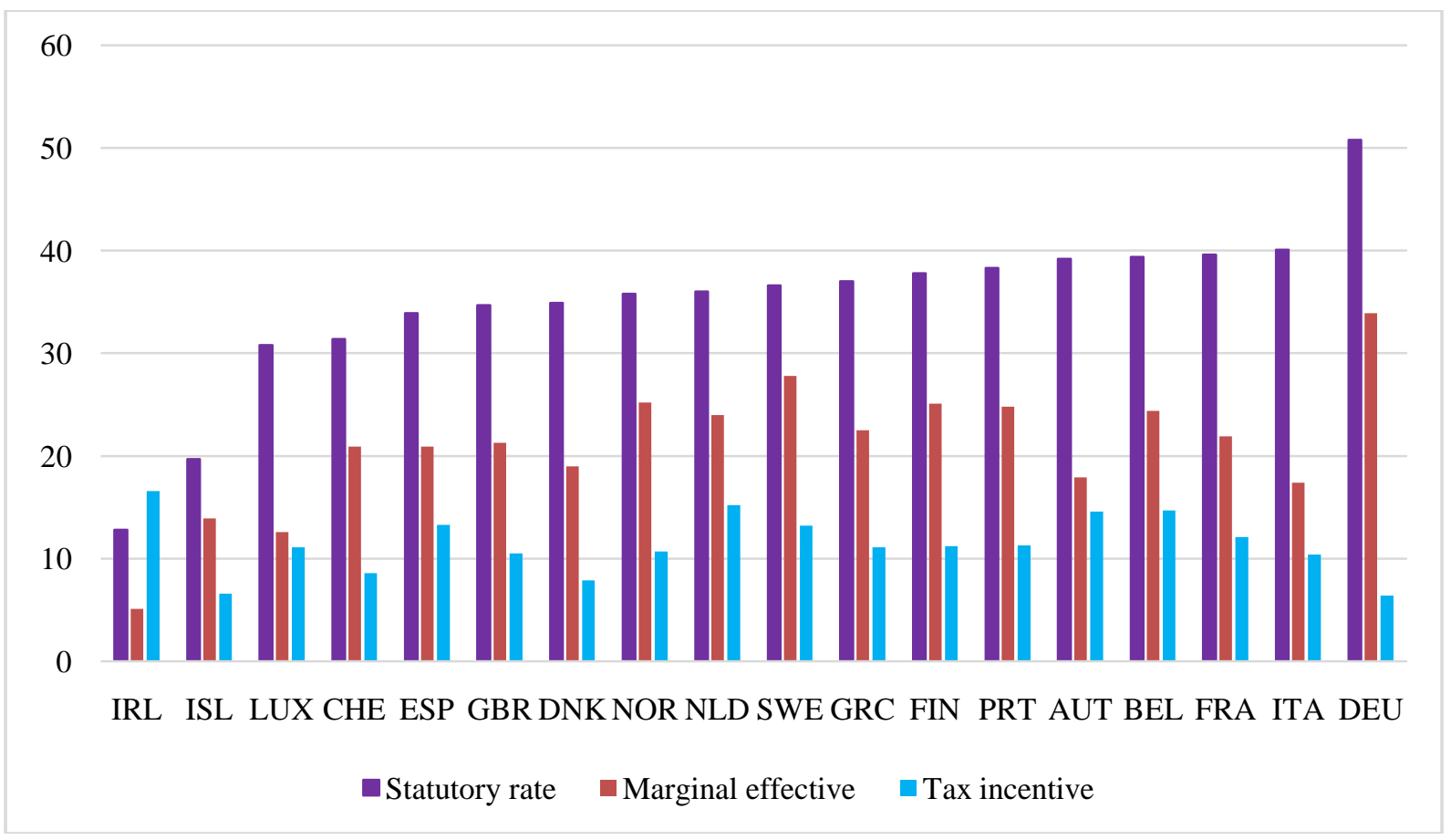


To further illustrate this we group, by country, in figure 4the statutory and marginal effective tax rates and the hand-collected tax incentives. This shows that Ireland, with the lowest statutory and marginal effective tax rates also offers the most incentives, while Italy facing among the highest statutory tax rates offers among the least generous incentives, suggesting that tax incentives are complement to attractive tax rates, making the tax regime even more attractive, rather than a substitute for high tax rates.

Figure 5. Statutory tax rates and tax incentives (ERTINCENT and REAVINCENT)

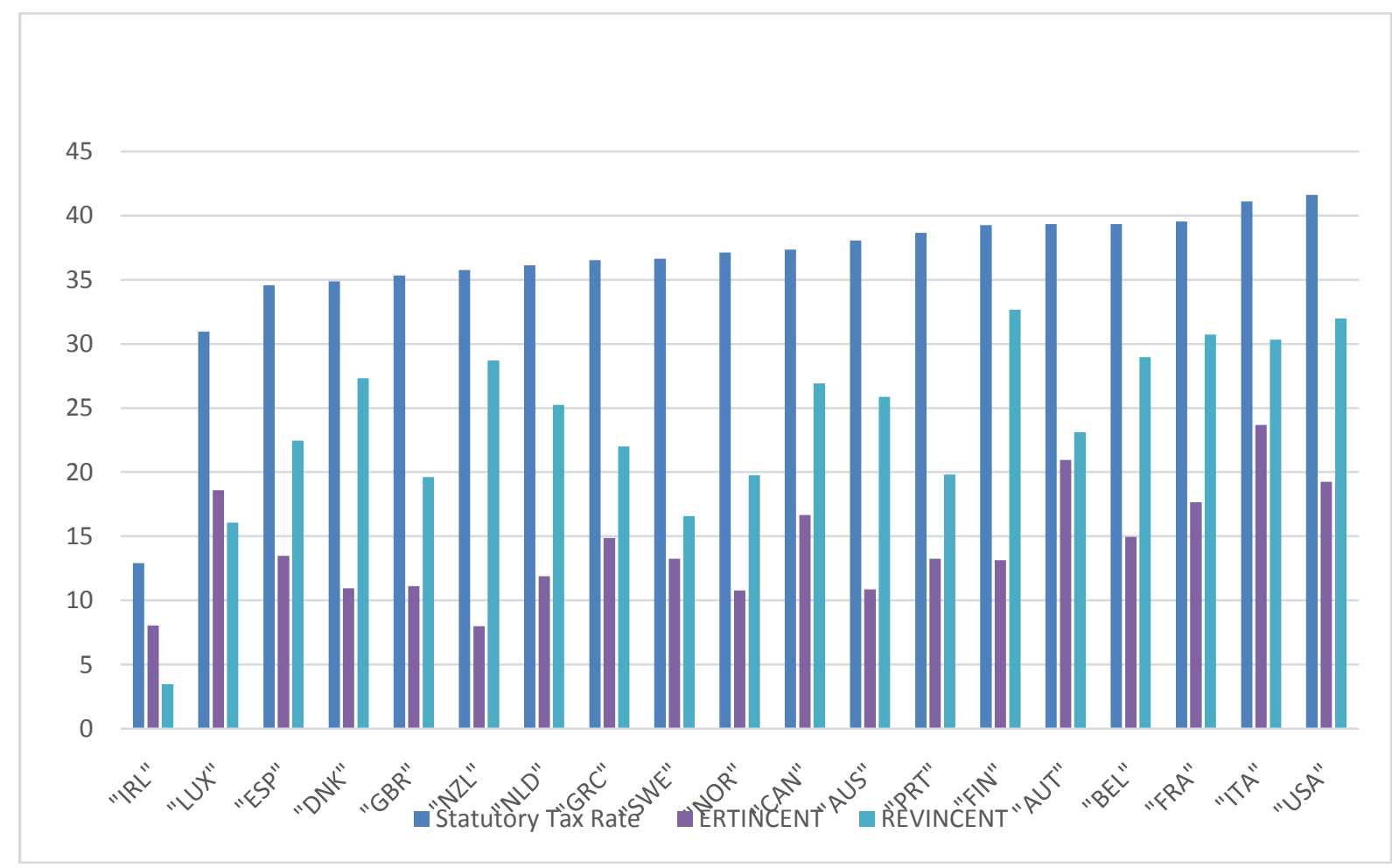

The picture in figure 5, illustrating the statutory tax rate and the other two tax incentives, is somewhat different, however. Here there seems to be a positive correlation between the statutory tax rate and the incentives offered suggesting that tax incentives are offered to compensate for high statutory tax rates. To determine whether tax incentives work as complements or substitutes a more rigorous analysisis needed.

\section{Estimation approach}

We now turn to the estimation of tax incentives in order to investigate what explains tax incentives and to test whether countries act strategically when deciding upon tax incentives.

More specifically, we model tax incentives as:

$T I_{i t}=\beta X_{i t-1}+\gamma Y_{i t-1}+\delta \bar{T}_{i t}+\mu_{i}+\varepsilon_{i t}$

$T I_{i t}$ is our tax incentive measure and is one of our three measures of tax incentives discussed previously. $X_{i t-1}$ captures economic factors including the statutory corporate tax rate, size (measured as Gross Domestic Product, GDP, in US dollar), openness, government size, relative real world growth rate (measured as the countries' economic growth rate relative to the average growth rate in OECD countries), national debt, the interest rate, the deficit and the index of economic freedom, all lagged one period.

Statutory tax ratesare predicted to be positively correlated with the level of incentives if tax incentives are used as substitutes. Hansson et al. (2015) found that countries with political structures limiting their ability to compete in the race to the bottom regarding statutory tax rates had higher levels of tax incentives. Tax incentives can, hence, compensate for high corporate tax rates. On the other hand, if generous tax incentives are offered to complement low statutory tax rates we expect a negative correlation between statutory tax rates and tax incentives. GDP in current purchasing power (in billions of US dollars) is our size measure and is expected to be negatively correlated with tax incentives. 
This relation is consistent with both the traditional tax competition literature and New Economic Geography literature as larger countries tend to enjoy agglomeration economies to a larger degree than small countries, and can hence allow themselves to be less competitive when it comes to tax climate. Openness is total trade as a fraction of GDP and is predicted to positively correlate with tax incentives. However, this relationship could be the opposite if trade leads to agglomeration effects and the ability to tax the resulting extra rent. Government size is total government expenditures as a fraction of GDP and measures the degree of public consumption. Prior research has shown the corporate tax burden to be higher in countries with larger governments as the government needs additional revenues to fund infrastructure (Ghinamo et al., 2007; Slemrod, 2004; and Heinemann et al., 2010). Historically, as the corporate tax rate decreased over time, the tax base increased. As a result, we expect a positive correlation between the level of incentives and government size.

We also include the long-term interest rate on government bonds as an indicator of the business cycle climate. We predict a positive correlation between the level of incentives and interest rates suggesting that a weak business climate increases the need for tax incentives to stimulate the economy. Relative real world growth (measured as the countries' economic growth relative to the growth in OECD countries) measures how the country is growing relative to the remaining countries in the OECD. We predict that the prior year level of relative real world growth will be positively correlated with the level of incentives if countries try to maintain their level of growth. The level of national debt divided by GDP is included to measure the long-term economic condition of the country and is expected to be positively correlated with the level of incentives as we predict countries will use tax incentives to stimulate the economy. The level of the deficit is included as a short term measure of the countries' economy. Countries may increase incentives to stimulate the economy in the short term resulting in a positive correlation, conversely, they may decrease incentives to decrease the deficit. The Economic Freedom of the World Index is a composite index that considers the size of government, legal system and property rights, sound money, freedom to trade internationally and regulation. This composite index proxies for the business environment, including such factors as corruption, infrastructure and trade practices. James (2009) found that investment climate is an important factor explaining the effectiveness of tax incentives. As the Economic Freedom Index proxies for investment climate, we expect a negative correlation if countries with a friendly business climate need fewer incentives to encourage business growth. However, if incentives become more effective in a business friendly environment we would expect a positive correlation. In addition and consistent with prior research, we include political variables, represented in the vector $Y_{i t-1}$, all lagged one year. Included in the political vector are measures of government party and political transaction costs. The government party variable measures whether the sitting government is left, center, or right wing. It ranks from one to five, where one reflects having a right-wing government and five a left-wing party. The higher the value the more left-wing the government is. We expect more left-wing oriented governments to have fewer incentives, though the relationship could be the opposite if left-wing parties are concerned that lower levels of incentives lower investments and cause unemployment. Our political transaction cost measures include legislative fractionalization, institutional constraint, and political structure.

Legislative fractionalization of the party system is an index measured according to a method developed by Rae (1968). ${ }^{3}$ The higher the value the more fractionalized the legislative power. We expect this variable to have a negative impact on incentives as more fractionalized governments possess less power to implement tax reforms (see e.g., Ashworth \&Heyndels, 2001, 2002).

Institutional constraint is an additive index that measures the institutional constraints put on the government (compiled by Schmidt, 1996). It ranks from 0 to 5 where a value of 0 indicates a large maneuvering room for the central government and the higher values indicate the most constrained central government. These composite variable proxies for the constitutional and rule of law restrictions put on legislators which are components of political transaction costs. As a result, a negative correlation is predicted between institutional constraints and incentives. Conversely, Hansson et al. (2015) found that countries that were politically constrained to reduce high tax rates were more likely to offer incentives if they had a high level of institutional constraints.

${ }^{3}$ Specifically, legislative fractionalization, rea_leg, is measured as $r$ a $\underline{e l}$ e $z 1-\sum_{\mathrm{i}=1}^{\mathrm{m}} s_{i}^{2}$, where $s_{i}$ is share of seats for party $i$ and $m$ is the number of parties. Hence, if only one party has legislative power rae_leg is equal to zero. 130 
They argue that the incentives were easier to pass through the institutional constraints than a change in statutory tax rates. Hence, we would expect a positive correlation between incentives and institutional constraints.

The third political transaction cost, structure, reflects the constitutional structure of the country and comprises a number of different components including federalism and bicameralism and whether the government is presidential or parliamentary. The components consider how many voices are considered when laws are changed. For example, a bicameral legislature generally requires a concurrent majority to pass legislation measures. This composite variable proxies for separation of powers, federalism and legislative supremacy components of political transaction costs. We also expect this variable to have a positive coefficient. The second last term before the error term in equation (3) represents the strategic interaction. This captures how other countries' tax incentives impact the home country's tax incentives. Ideally, we would like to include a separate variable for each country's tax incentive but this leads to an over-parameterization problem (LeSage\& Pace, 2009). Instead, we use a spatial lag model that uses a weighted average of the tax incentives of countries with a strategic dependence. This approach has been used previously in many studies including Devereux et al. (2006, 2008) and Brueckner (2003). By construction, $\bar{T}_{j t}$ is the weighted average of strategic interaction multiplied by the respective tax incentive in the foreign countries, respectively. We thus have:

$\bar{T}_{j t}=\sum_{j \neq i} w_{i j} T_{j t}$ and $\sum_{j \neq i} w_{i j}=1$

where $w_{i j}$ are weights and $\mathrm{T}_{\mathrm{jt}}$ is the tax incentive in country $j$ at time $t$. The spatial weights are inversely related to the geographical distance and population between country $i$ and $j$. The logic is that a generous tax incentive in a geographically close country exercises a larger impact on country $i$ 's tax incentive than a generous tax incentive in a geographically remote country. We thus predict a positive coefficient on the tax incentive strategic interaction term. Population provides a measure of the interaction of distance and influence. Specifically, the weights are calculated as follows:

$w_{i j}=\frac{\frac{\ln \left(\text { pop }_{j}\right)}{d_{i j}^{2}}}{\sum_{j \neq i} \frac{\ln \left(\text { poo }_{j}\right)}{d_{i j}^{2}}}$

whered is the geographical distance between capitals for each pair of countries and pop is the total population. Distance is squared to emphasize the geographical distance for equal size populations. Because of strategic interaction, the tax incentives are jointly determined in the different jurisdictions. The tax incentives on the right hand side of the equation are endogenous and correlated with the error term. Hence, ordinary least squares estimations of the parameters are inconsistent. We deal with this issue in two ways. First, we use a spatial lag model where the weighted composite tax incentive variable on the right hand side uses a lagged tax incentives (LeSage\& Pace, 2009). Second, we use an instrument variables (IV) approach. Under this approach we regress $w T$ on $X$ and $Y$ and use the fitted values as instruments for $w T$.Finally, we include country specific factors to account for confounding factors, and the error term.

\section{What determines tax incentives?}

Table 1 reports results of economic and political determinants of tax incentives, using the three different tax incentives measures (REVINCENT, ETRINCENT, and HANDINCENT). For REVINCENT and ETRINCENT the specifications using FE and IV with year dummies are presented, respectively. As HANDINCENT is an index ranging from two to 19, where two corresponds to few tax incentives and 19 to more and more generous tax incentives, we employ ordered probit and logit models. The first column for HANDINCENT report the results from the probitestimation with year effects, and the last column reports the results from the corresponding log it estimation.

The results vary across the different incentives. Starting with the tax rates, the statutory corporate tax rates, are positively and significantly correlated with REVINCENT and ETRINCENT, suggesting that countries with higher statutory tax rates offset this by offering tax incentives in order to reduce the effective tax rate. That is tax incentives work as substitutes to high statutory tax rates. Interestingly, the statutory corporate tax rates are negatively correlated with the hand-collected incentives. The difference in the results may be attributed to how the tax incentive measures differ. The hand-collected variable is an index of number of incentives offered and does not measure the magnitude of the incentive. 
Table 1. Tax Incentive Determinants

\begin{tabular}{|c|c|c|c|c|c|c|}
\hline & $\begin{array}{l}\text { REVINCENT } \\
\text { Fixed effects } \\
\end{array}$ & $\begin{array}{c}\text { REVINCENT } \\
\text { Instrument }\end{array}$ & $\begin{array}{l}\text { ETRINCENT } \\
\text { Fixed effects }\end{array}$ & $\begin{array}{c}\text { ETRINCENT } \\
\text { Instrument } \\
\end{array}$ & $\begin{array}{l}\text { HANDINCENT } \\
\text { Probit } \\
\end{array}$ & $\begin{array}{c}\text { HANDINCENT } \\
\text { Logit } \\
\end{array}$ \\
\hline Statutory tax rate & $\begin{array}{c}0.619 * * * \\
(0.0595)\end{array}$ & $\begin{array}{c}0.604 * * * \\
(0.0638)\end{array}$ & $\begin{array}{c}0.326 * * * \\
(0.0920)\end{array}$ & $\begin{array}{c}0.280 * * * \\
(0.0872)\end{array}$ & $\begin{array}{c}-7.634 * * * \\
(1.173)\end{array}$ & $\begin{array}{c}-13.78 * * * \\
(2.494)\end{array}$ \\
\hline GDP dollar & $\begin{array}{l}0.147 * * \\
(0.0699)\end{array}$ & $\begin{array}{l}0.157 * * \\
(0.0735)\end{array}$ & $\begin{array}{c}0.0509 \\
(0.0823)\end{array}$ & $\begin{array}{c}0.0626 \\
(0.0840)\end{array}$ & $\begin{array}{c}0.533 * * * \\
(0.105)\end{array}$ & $\begin{array}{c}0.951 * * * \\
(0.221)\end{array}$ \\
\hline Trade & $\begin{array}{c}0.000462 \\
(0.000368)\end{array}$ & $\begin{array}{c}0.000494 \\
(0.000376)\end{array}$ & $\begin{array}{c}0.000421 \\
(0.000608)\end{array}$ & $\begin{array}{c}0.000358 \\
(0.000561)\end{array}$ & $\begin{array}{c}0.0150 * * * \\
(0.00203)\end{array}$ & $\begin{array}{c}0.0262 * * * \\
(0.00391)\end{array}$ \\
\hline Gov't size & $\begin{array}{l}-0.00127 \\
(0.00130)\end{array}$ & $\begin{array}{l}-0.001000 \\
(0.00152)\end{array}$ & $\begin{array}{l}-0.000252 \\
(0.00192)\end{array}$ & $\begin{array}{l}5.84 \mathrm{e}-05 \\
(0.00204)\end{array}$ & $\begin{array}{c}0.0186 \\
(0.0200)\end{array}$ & $\begin{array}{c}0.0324 \\
(0.0455)\end{array}$ \\
\hline Interest rate & $\begin{array}{l}0.00604 * \\
(0.00306)\end{array}$ & $\begin{array}{l}0.00640 * \\
(0.00375)\end{array}$ & $\begin{array}{c}0.00296 \\
(0.00489)\end{array}$ & $\begin{array}{c}0.00326 \\
(0.00476)\end{array}$ & $\begin{array}{l}-0.0450 \\
(0.0860)\end{array}$ & $\begin{array}{l}-0.0905 \\
(0.187)\end{array}$ \\
\hline $\begin{array}{l}\text { Rel real world } \\
\text { growth }\end{array}$ & $\begin{array}{c}0.00103 \\
(0.00129)\end{array}$ & $\begin{array}{c}0.00106 \\
(0.00165)\end{array}$ & $\begin{array}{c}0.00483 * * \\
(0.00183)\end{array}$ & $\begin{array}{l}0.00460 * * \\
(0.00204)\end{array}$ & $\begin{array}{l}0.0971 * \\
(0.0526)\end{array}$ & $\begin{array}{c}0.144 \\
(0.104)\end{array}$ \\
\hline Debt/GDP & $\begin{array}{l}-0.000540 \\
(0.000375)\end{array}$ & $\begin{array}{l}-0.000473 \\
(0.000389)\end{array}$ & $\begin{array}{c}0.000225 \\
(0.000773)\end{array}$ & $\begin{array}{c}0.000223 \\
(0.000823)\end{array}$ & $\begin{array}{l}0.0103 * * * \\
(0.00348)\end{array}$ & $\begin{array}{l}0.0201 * * * \\
(0.00700)\end{array}$ \\
\hline Deficit & $\begin{array}{c}-0.00672 * * * \\
(0.00150)\end{array}$ & $\begin{array}{c}-0.00714 * * * \\
(0.00251)\end{array}$ & $\begin{array}{l}-0.00119 \\
(0.00164)\end{array}$ & $\begin{array}{l}-0.000944 \\
(0.00174)\end{array}$ & $\begin{array}{l}0.0645^{*} \\
(0.0379)\end{array}$ & $\begin{array}{c}0.136 \\
(0.0861)\end{array}$ \\
\hline Index econ freedom & $\begin{array}{c}3.76 \mathrm{e}-05 \\
(0.00136)\end{array}$ & $\begin{array}{l}-9.35 \mathrm{e}-05 \\
(0.00159)\end{array}$ & $\begin{array}{c}0.00169 \\
(0.00187)\end{array}$ & $\begin{array}{c}0.00209 \\
(0.00185)\end{array}$ & $\begin{array}{l}-0.0261 \\
(0.0185)\end{array}$ & $\begin{array}{l}-0.0342 \\
(0.0382)\end{array}$ \\
\hline Gov't party & $\begin{array}{l}-4.20 \mathrm{e}-05 \\
(0.00202)\end{array}$ & $\begin{array}{l}-0.00150 \\
(0.00218)\end{array}$ & $\begin{array}{c}0.00154 \\
(0.00308)\end{array}$ & $\begin{array}{c}0.00218 \\
(0.00363)\end{array}$ & $\begin{array}{c}-0.129 * * * \\
(0.0452)\end{array}$ & $\begin{array}{l}-0.172 * \\
(0.0905)\end{array}$ \\
\hline Fractionalization & $\begin{array}{l}-0.000477 \\
(0.000809)\end{array}$ & $\begin{array}{l}-0.000356 \\
(0.000936)\end{array}$ & $\begin{array}{l}9.17 \mathrm{e}-05 \\
(0.00117)\end{array}$ & $\begin{array}{l}-0.000185 \\
(0.00127)\end{array}$ & $\begin{array}{c}-0.00474 \\
(0.0151)\end{array}$ & $\begin{array}{r}-0.00879 \\
(0.0359)\end{array}$ \\
\hline $\begin{array}{l}\text { Institutional } \\
\text { constraint }\end{array}$ & $\begin{array}{l}0.0167 * * \\
(0.00684)\end{array}$ & $\begin{array}{l}0.0188 * * \\
(0.00774)\end{array}$ & $\begin{array}{l}-0.00537 \\
(0.0153)\end{array}$ & $\begin{array}{c}-0.000486 \\
(0.0148)\end{array}$ & $\begin{array}{c}-0.537 * * * \\
(0.168)\end{array}$ & $\begin{array}{c}-1.046 * * * \\
(0.390)\end{array}$ \\
\hline Structure & $\begin{array}{c}-0.00182 \\
(0.0318)\end{array}$ & $\begin{array}{l}0.00225 \\
(0.0307)\end{array}$ & $\begin{array}{c}0.0811 * * \\
(0.0373)\end{array}$ & $\begin{array}{c}0.0888 * * \\
(0.0404)\end{array}$ & $\begin{array}{c}0.225 * * * \\
(0.0848)\end{array}$ & $\begin{array}{c}0.433 * * * \\
(0.158)\end{array}$ \\
\hline $\begin{array}{l}\text { Strategic interaction } \\
\text { taxincent } 1\end{array}$ & $\begin{array}{c}0.153 \\
(0.0910)\end{array}$ & $\begin{array}{c}0.122 \\
(0.500)\end{array}$ & & & & \\
\hline $\begin{array}{l}\text { Strategic interaction } \\
\text { taxbasem }\end{array}$ & & & $\begin{array}{l}-0.614 \\
(0.394)\end{array}$ & $\begin{array}{c}-1.062 * * \\
(0.490)\end{array}$ & & \\
\hline $\begin{array}{l}\text { Strategic interaction } \\
\text { incenthc }\end{array}$ & & & & & $\begin{array}{c}-0.102 \\
(0.0695)\end{array}$ & $\begin{array}{l}-0.197 \\
(0.136)\end{array}$ \\
\hline Constant & $\begin{array}{c}-2.010 * * \\
(0.948)\end{array}$ & $\begin{array}{c}-2.170^{* *} \\
(1.016)\end{array}$ & $\begin{array}{l}-0.720 \\
(1.211)\end{array}$ & $\begin{array}{l}-0.726 \\
(1.211)\end{array}$ & & \\
\hline $\begin{array}{l}\text { Observations } \\
\text { R-squared }\end{array}$ & $\begin{array}{c}222 \\
0.794\end{array}$ & 206 & $\begin{array}{c}243 \\
0.370\end{array}$ & 225 & 202 & 202 \\
\hline Number of code & 20 & 20 & 22 & 22 & & \\
\hline
\end{tabular}

Robust standard errors in parentheses

$* * * \mathrm{p}<0.01, * * \mathrm{p}<0.05, * \mathrm{p}<0.1$

High statutory tax rates may be accompanied by fewer incentives, and vice versa, reflecting regimes that provide unattractive or attractive tax regimes (this was the pattern seen in figure 4). This suggests that tax incentives and tax rates work as complement. The number of incentives offered is, however, a poor measure of the magnitude and overall impact of incentives offered.

Most of the other control variables are insignificantly correlated with tax incentives. None of the other control variables are consistently significantly correlated across the different incentives. For our preferred tax incentive, REVINCENT, size has a positive correlation suggesting that larger countries offer more incentives. This also holds for the hand-collected incentives. Openness and level of debt also seems to be positively correlated with the hand-collected variables. Higher deficits seem to be associated with lower incentives (REVINCENT) favoring the view that deficits put pressure on countries to balance their budget and lower incentives. 
Turning to the political variables, party color only seems to matter for the hand-collected and, thus, the incentive measuring the number of incentives rather than magnitude of the incentives offered. The estimation result suggests that more left-wing parties offer fewer incentives. For the preferred incentive measure it appears that countries that are institutional constrained offer more incentives than countries that are less institutionally constrained. This supports results from Hansson et al. (2015) who found that countries that are institutionally constrained to lower tax rates tend to offer more tax incentives. For the other two incentives, structure (measuring how many voices that are needed to be heard to make law changes) impacts tax incentives positively. Hence, it seems that the harder it is to pass laws the more incentives are offered (either in magnitude or in numbers). This also supports the view that countries may compensate and offer incentives instead as they may be easier to pass than statutory tax rate declines. An alternative explanation is offered by Buchanan (2008), who argues that separation of power can lead to an increase in special interest spending which would imply that more specific incentives may be offered in countries where power is more separated.

Last, the strategic interaction term measuring whether other countries' incentives influence a home country's incentives suggests that countries do not act strategically when it comes to determining tax incentives. For the preferred and hand-collected incentive measure the coefficient is insignificant, and for ETRINCENT the coefficient is even negative. The insignificant and negative coefficients for the incentives indicate that both the wider and more targeted incentives offered in other countries do not affect incentives offered.

To further investigate whether countries that are institutionally constrained to lower their tax rates instead turn to offer tax incentives, we interact institutional constraint with the statutory corporate tax rate in order to test whether institutionally constrained high-tax countries offer more incentives than low-tax countries. The interaction term is positive and statistically significant for REVINCENT and for the hand-collected incentives indicating that high-tax countries that are constitutionally constrained tend to offer more generous and a larger number of incentives than low-tax countries that are institutionally constrained. ${ }^{4}$

\section{Taxes, tax incentives and investment}

Next, we turn to the question of whether tax incentives affect investments and are a more effective way to stimulate investments than lowering statutory tax rates. More generous tax incentives versus lower statutory tax rates are likely to impact different business activities differently. To benefit from a lower statutory tax rate the firm has to make a profit, and lower statutory tax rates are therefore more likely to benefit established firms making profits. Tax incentives, on the other hand, may benefit firms not yet making profits but enabling them to do so in the future. Tax incentives may be more beneficiary for start-ups and innovative firms than established firms, and, hence, it is not obvious what the overall effect will be. We analyze the effect of tax incentives and statutory tax rate on two different investment measures, namely, FDI inflows and gross fixed capital formation (GFCF). We start out by investigating FDI inflows and do this by estimating the following panel data model:

$\operatorname{lnFDI} I_{i t}=\theta T A X_{i t-1}+\beta X_{i t-1}+\mu_{i}+\varepsilon_{i t}$.

Where $\ln F D I_{i t}$ is natural logarithm of inflows of FDI in country $i$ at time $t$. Tax is our tax vector made up of the statutory corporate tax rate and our various tax incentive measures at time $t-1 . X_{i t-I}$ captures other control variables affecting FDI such as GDP per capita, relative world growth rate, openness measured as change in total trade over GDP, government size, debt, deficit, and interest rates.

We expect GDP per capita and openness to be positively correlated with FDI flows, while the correlation between government size and FDI may be less obvious and depends on what the government provides and how it is financed. The components of government spending resulting in efficient institutions and good infrastructure are likely positively correlated with FDI while spending components to transfers may be negatively correlated. The interest on long-term bonds is our business-cycle variable and we expect this to have a negative impact on FDI. We additionally, include political variables (fractionalization, government party, institutional constraint, and structure) as we expect these to affect inflows of FDI. We predict that uncertainty about government changes in the future increases the risk of investing in a country and, hence, more stable policies may increase investments.

The tax measures analyzed are apart from the statutory corporate tax rate and the three aggregate measures: depreciation rules, loss off-setting rules, number of tax treaties, investment credits, R\&D incentives, enterprise zones, and incentives for new and small firms.

\footnotetext{
${ }^{4}$ The results are not presented but can be obtained from the authors.
} 
Similarly and in addition to FDI, we also determine how tax incentives affect gross fixed capital formation. Gross fixed capital formation is a wider measure of capital formation that captures the acquisition of new or existing fixed assets by the business sector, government and households minus disposals of fixed assets. Gross fixed capital formation does not measure the total investment but rather the net addition and excludes all kinds of financial assets. Specifically, we regress

$$
\operatorname{lnGFCF}_{i t}=\delta T A X_{i t-1}+\beta X_{i t-1}+\mu_{i}+\varepsilon_{i t} \text {, }
$$

Where $\ln G F C F_{i t}$ is natural logarithm of gross fixed capital formation measured in US dollars in country $i$ at time $t t^{5}$ Tax is our tax vector made up of the level of corporate tax rate and our various tax incentive measures at time t-1. $X_{i t-1}$ captures other control variables (lagged one period) that may impact gross fixed capital formation such as GDP per capita, relative world growth rate, openness measured as total trade over GDP, government size, debt and deficit, and interest rates.

Table 2. FDI and Aggregate Tax Incentives

\begin{tabular}{|c|c|c|c|c|}
\hline & FDI & FDI & FDI & FDI \\
\hline Statutory tax rate & $\begin{array}{c}-7.310 * * * \\
(1.864)\end{array}$ & $\begin{array}{c}-8.634 * * \\
(3.549)\end{array}$ & $\begin{array}{c}-7.310^{* * * *} \\
(2.097)\end{array}$ & $\begin{array}{c}-7.725 * * * \\
(2.149)\end{array}$ \\
\hline REVINCENT & & $\begin{array}{c}3.277 \\
(4.279)\end{array}$ & & \\
\hline ETRINCENT & & & $\begin{array}{c}-0.000295 \\
(1.715)\end{array}$ & \\
\hline HANDINCENT & & & & $\begin{array}{c}-0.0237 \\
(0.0290)\end{array}$ \\
\hline GDP per cpaita & $\begin{array}{c}6.172 * * * \\
(2.169)\end{array}$ & $\begin{array}{c}3.824 \\
(2.385)\end{array}$ & $\begin{array}{c}6.172 * * \\
(2.175)\end{array}$ & $\begin{array}{c}6.519 * * * \\
(2.177)\end{array}$ \\
\hline Rel real world & -0.0417 & -0.0381 & -0.0417 & -0.0298 \\
\hline Growth & $(0.0999)$ & $(0.0960)$ & $(0.100)$ & $(0.124)$ \\
\hline Trade & $\begin{array}{c}-0.00612 \\
(0.0125)\end{array}$ & $\begin{array}{c}-0.00958 \\
(0.0145)\end{array}$ & $\begin{array}{c}-0.00612 \\
(0.0125)\end{array}$ & $\begin{array}{r}-0.00299 \\
(0.0140)\end{array}$ \\
\hline Debt/GDP & $\begin{array}{c}0.000459 \\
(0.00126)\end{array}$ & $\begin{array}{c}0.000167 \\
(0.00143)\end{array}$ & $\begin{array}{c}0.000459 \\
(0.00126)\end{array}$ & $\begin{array}{l}0.000945 \\
(0.00168)\end{array}$ \\
\hline Deficit & $\begin{array}{c}-0.0350 \\
(0.0508)\end{array}$ & $\begin{array}{c}-0.0466 \\
(0.0487)\end{array}$ & $\begin{array}{l}-0.0350 \\
(0.0510)\end{array}$ & $\begin{array}{l}-0.0145 \\
(0.0720)\end{array}$ \\
\hline Gov't size & $\begin{array}{l}-0.0272 \\
(0.0570)\end{array}$ & $\begin{array}{l}-0.0505 \\
(0.0626)\end{array}$ & $\begin{array}{l}-0.0272 \\
(0.0573)\end{array}$ & $\begin{array}{r}-0.00502 \\
(0.0785)\end{array}$ \\
\hline Interest rate & $\begin{array}{c}0.0675 \\
(0.0638)\end{array}$ & $\begin{array}{c}0.0250 \\
(0.0939)\end{array}$ & $\begin{array}{c}0.0675 \\
(0.0638)\end{array}$ & $\begin{array}{c}0.0857 \\
(0.0586)\end{array}$ \\
\hline Index econ freedom & $\begin{array}{c}-0.0470 \\
(0.0320)\end{array}$ & $\begin{array}{c}-0.0690 \\
(0.0402)\end{array}$ & $\begin{array}{c}-0.0470 \\
(0.0320)\end{array}$ & $\begin{array}{l}-0.0485 \\
(0.0327)\end{array}$ \\
\hline Gov't party & $\begin{array}{c}0.0520 \\
(0.0499)\end{array}$ & $\begin{array}{c}0.0424 \\
(0.0473)\end{array}$ & $\begin{array}{c}0.0520 \\
(0.0492)\end{array}$ & $\begin{array}{c}0.0319 \\
(0.0585)\end{array}$ \\
\hline Fractionalization & $\begin{array}{c}-0.0109 \\
(0.0158)\end{array}$ & $\begin{array}{r}-0.00327 \\
(0.0174)\end{array}$ & $\begin{array}{l}-0.0109 \\
(0.0158)\end{array}$ & $\begin{array}{l}-0.0122 \\
(0.0152)\end{array}$ \\
\hline $\begin{array}{l}\text { Institutional } \\
\text { constraints }\end{array}$ & $\begin{array}{l}0.454^{*} \\
(0.244)\end{array}$ & $\begin{array}{l}0.390^{*} \\
(0.223)\end{array}$ & $\begin{array}{l}0.454 * \\
(0.244)\end{array}$ & $\begin{array}{l}0.481^{*} \\
(0.267)\end{array}$ \\
\hline Structure & $\begin{array}{l}0.416^{*} \\
(0.223)\end{array}$ & $\begin{array}{c}0.389 \\
(0.236)\end{array}$ & $\begin{array}{l}0.416^{*} \\
(0.233)\end{array}$ & $\begin{array}{c}0.361 \\
(0.238)\end{array}$ \\
\hline Constant & $\begin{array}{c}-49.01 * * \\
(21.98)\end{array}$ & $\begin{array}{l}-21.81 \\
(23.17)\end{array}$ & $\begin{array}{c}-49.01 * * \\
(22.04)\end{array}$ & $\begin{array}{c}-53.27 * * \\
(22.67)\end{array}$ \\
\hline Observations & 234 & 211 & 234 & 195 \\
\hline R-squared & 0.491 & 0.468 & 0.491 & 0.502 \\
\hline Number of code & 21 & 19 & 21 & 18 \\
\hline
\end{tabular}

Robust standard errors in parentheses

$* * * \mathrm{p}<0.01, * * \mathrm{p}<0.05, * \mathrm{p}<0.1$

${ }^{5}$ Gross fixed capital formation comes from UN. 


\subsection{Results}

Table 2 reports the results for inflow of FDI with the statutory corporate tax rate and our three aggregate tax incentive measures. The statutory corporate tax rate has a negative and statistically significant impact on FDI flows, with a semi-elasticity of -7.3. That is, a one percentage point increase in the corporate tax rate is associated with 7.3 percent lower FDI inflows. This estimate is fairly high, but approximately in line with tax semielasticities for FDI. The semi-elasticity for the corporate tax rate remains significant and in the same order of magnitude when tax incentives are included, as shown in the following columns. However, neither of the aggregate tax incentives have

Table 3. FDI and individual Tax Incentives

\begin{tabular}{|c|c|c|c|c|c|c|c|}
\hline & FDI & FDI & FDI & FDI & FDI & FDI & FDI \\
\hline Statutory tax rate & $\begin{array}{c}-7.771 * * * \\
(2.114)\end{array}$ & $\begin{array}{c}-7.412 * * * \\
(2.233)\end{array}$ & $\begin{array}{c}-6.179 * * \\
(2.213)\end{array}$ & $\begin{array}{c}-7.727 * * * \\
(2.135)\end{array}$ & $\begin{array}{c}-7.415^{* * * *} \\
(2.129)\end{array}$ & $\begin{array}{c}-7.642 * * * \\
(2.106)\end{array}$ & $\begin{array}{c}-7.746 * * * \\
(2.003)\end{array}$ \\
\hline Depreciation & $\begin{array}{c}0.142 \\
(0.215)\end{array}$ & & & & & & \\
\hline Loss rules & & $\begin{array}{l}-0.306 \\
(0.283)\end{array}$ & & & & & \\
\hline Tax treaties & & & $\begin{array}{c}0.0507 * * * \\
(0.0168)\end{array}$ & & & & \\
\hline Investment tax & & & & -0.0743 & & & \\
\hline Credit & & & & $(0.252)$ & & & \\
\hline R\&D & & & & & $\begin{array}{l}-0.150 \\
(0.208)\end{array}$ & & \\
\hline $\begin{array}{l}\text { Enterprise } \\
\text { Zone }\end{array}$ & & & & & & $\begin{array}{l}-0.177 \\
(0.151)\end{array}$ & \\
\hline $\begin{array}{l}\text { New and small } \\
\text { Firm }\end{array}$ & & & & & & & $\begin{array}{l}0.364^{*} \\
(0.199)\end{array}$ \\
\hline GDP per capita & $\begin{array}{l}6.616^{* *} \\
(2.310)\end{array}$ & $\begin{array}{l}6.105^{* *} \\
(2.270)\end{array}$ & $\begin{array}{c}6.246 * * * \\
(1.980)\end{array}$ & $\begin{array}{c}6.408 * * * \\
(2.158)\end{array}$ & $\begin{array}{c}6.470 * * * \\
(2.225)\end{array}$ & $\begin{array}{c}6.496^{* *} \\
(2.245)\end{array}$ & $\begin{array}{l}6.374 * * \\
(2.203)\end{array}$ \\
\hline $\begin{array}{l}\text { Rel real world } \\
\text { Growth }\end{array}$ & $\begin{array}{l}-0.0397 \\
(0.125)\end{array}$ & $\begin{array}{c}-0.0286 \\
(0.127)\end{array}$ & $\begin{array}{l}0.0218 \\
(0.121)\end{array}$ & $\begin{array}{c}-0.0333 \\
(0.126)\end{array}$ & $\begin{array}{c}-0.0317 \\
(0.125)\end{array}$ & $\begin{array}{c}-0.0288 \\
(0.118)\end{array}$ & $\begin{array}{c}-0.0352 \\
(0.120)\end{array}$ \\
\hline Trade & $\begin{array}{l}-0.00173 \\
(0.0140)\end{array}$ & $\begin{array}{l}-0.00261 \\
(0.0137)\end{array}$ & $\begin{array}{l}-0.00736 \\
(0.0121)\end{array}$ & $\begin{array}{l}-0.00193 \\
(0.0142)\end{array}$ & $\begin{array}{l}-0.00232 \\
(0.0142)\end{array}$ & $\begin{array}{c}-0.000848 \\
(0.0149)\end{array}$ & $\begin{array}{c}-0.000795 \\
(0.0138)\end{array}$ \\
\hline Debt/GDP & $\begin{array}{c}0.00102 \\
(0.00168)\end{array}$ & $\begin{array}{l}0.000962 \\
(0.00167)\end{array}$ & $\begin{array}{l}0.000458 \\
(0.00145)\end{array}$ & $\begin{array}{c}0.00101 \\
(0.00164)\end{array}$ & $\begin{array}{l}0.000810 \\
(0.00170)\end{array}$ & $\begin{array}{l}0.000975 \\
(0.00172)\end{array}$ & $\begin{array}{l}0.000914 \\
(0.00150)\end{array}$ \\
\hline Deficit & $\begin{array}{l}-0.0247 \\
(0.0743)\end{array}$ & $\begin{array}{l}-0.0161 \\
(0.0717)\end{array}$ & $\begin{array}{l}-0.0258 \\
(0.0649)\end{array}$ & $\begin{array}{l}-0.0211 \\
(0.0735)\end{array}$ & $\begin{array}{l}-0.0160 \\
(0.0730)\end{array}$ & $\begin{array}{l}-0.0154 \\
(0.0764)\end{array}$ & $\begin{array}{l}-0.0161 \\
(0.0705)\end{array}$ \\
\hline Gov't size & $\begin{array}{l}-0.0220 \\
(0.0790)\end{array}$ & $\begin{array}{l}-0.00983 \\
(0.0786)\end{array}$ & $\begin{array}{c}-0.0494 \\
(0.0632)\end{array}$ & $\begin{array}{l}-0.0155 \\
(0.0777)\end{array}$ & $\begin{array}{l}-0.00534 \\
(0.0797)\end{array}$ & $\begin{array}{r}-0.00455 \\
(0.0827)\end{array}$ & $\begin{array}{l}-0.00597 \\
(0.0713)\end{array}$ \\
\hline Interest rate & $\begin{array}{c}0.0740 \\
(0.0528)\end{array}$ & $\begin{array}{c}0.0691 \\
(0.0555)\end{array}$ & $\begin{array}{c}0.0440 \\
(0.0465)\end{array}$ & $\begin{array}{c}0.0792 \\
(0.0562)\end{array}$ & $\begin{array}{c}0.0816 \\
(0.0553)\end{array}$ & $\begin{array}{c}0.0693 \\
(0.0511)\end{array}$ & $\begin{array}{c}0.0741 \\
(0.0599)\end{array}$ \\
\hline Index econ freedom & $\begin{array}{l}-0.0492 \\
(0.0338)\end{array}$ & $\begin{array}{l}-0.0411 \\
(0.0349)\end{array}$ & $\begin{array}{c}-0.0462 \\
(0.0309)\end{array}$ & $\begin{array}{c}-0.0502 \\
(0.0338)\end{array}$ & $\begin{array}{l}-0.0504 \\
(0.0335)\end{array}$ & $\begin{array}{l}-0.0560 * \\
(0.0314)\end{array}$ & $\begin{array}{c}-0.0673 * * \\
(0.0274)\end{array}$ \\
\hline Gov't party & $\begin{array}{c}0.0380 \\
(0.0606)\end{array}$ & $\begin{array}{c}0.0205 \\
(0.0628)\end{array}$ & $\begin{array}{l}0.00826 \\
(0.0626)\end{array}$ & $\begin{array}{c}0.0355 \\
(0.0595)\end{array}$ & $\begin{array}{c}0.0310 \\
(0.0580)\end{array}$ & $\begin{array}{c}0.0320 \\
(0.0641)\end{array}$ & $\begin{array}{c}0.0232 \\
(0.0614)\end{array}$ \\
\hline Fractionalization & $\begin{array}{l}-0.0172 \\
(0.0167)\end{array}$ & $\begin{array}{l}-0.0196 \\
(0.0155)\end{array}$ & $\begin{array}{l}0.00420 \\
(0.0133)\end{array}$ & $\begin{array}{c}-0.0140 \\
(0.0158)\end{array}$ & $\begin{array}{c}-0.0114 \\
(0.0158)\end{array}$ & $\begin{array}{c}-0.0133 \\
(0.0151)\end{array}$ & $\begin{array}{c}-0.0160 \\
(0.0158)\end{array}$ \\
\hline Institutional & $0.497 *$ & 0.444 & $0.500 * *$ & $0.493 *$ & $0.519 *$ & $0.550 *$ & $0.511 *$ \\
\hline Constraint & $(0.269)$ & $(0.269)$ & $(0.218)$ & $(0.272)$ & $(0.257)$ & $(0.284)$ & $(0.257)$ \\
\hline Structure & $\begin{array}{c}0.343 \\
(0.223)\end{array}$ & $\begin{array}{c}0.391 \\
(0.250)\end{array}$ & $\begin{array}{l}-0.0451 \\
(0.236)\end{array}$ & $\begin{array}{c}0.327 \\
(0.223)\end{array}$ & $\begin{array}{c}0.348 \\
(0.228)\end{array}$ & $\begin{array}{l}0.389 * \\
(0.186)\end{array}$ & $\begin{array}{c}0.301 \\
(0.185)\end{array}$ \\
\hline Constant & $\begin{array}{c}-53.56 * * \\
(23.87)\end{array}$ & $\begin{array}{l}-48.45^{*} \\
(23.78)\end{array}$ & $\begin{array}{c}-53.19 * * \\
(21.65)\end{array}$ & $\begin{array}{c}-51.66 * * \\
(22.39)\end{array}$ & $\begin{array}{c}-53.08 * * \\
(23.48)\end{array}$ & $\begin{array}{c}-53.07 * * \\
(23.33)\end{array}$ & $\begin{array}{c}-50.70 * * \\
(22.94)\end{array}$ \\
\hline Observations & 195 & 195 & 195 & 195 & 195 & 195 & 195 \\
\hline R-squared & 0.500 & 0.503 & 0.532 & 0.500 & 0.501 & 0.502 & 0.511 \\
\hline Number of code & 18 & 18 & 18 & 18 & 18 & 18 & 18 \\
\hline
\end{tabular}

Robust standard errors in parentheses $* * * \mathrm{p}<0.01, * * \mathrm{p}<0.05, * \mathrm{p}<0.1$ 
A significant positive impact on FDI inflows. Our broadest and preferred measure of incentives, REVINCENT, has a positive though insignificant impact on FDI flows. Turning to the economic variables, most variables are insignificant. The only significant variableis GDP per capita. Larger countries attract more FDI than small countries. Among the political variables institutional constraints are significantly (at 10 percent) correlated with FDI inflows in all specifications. In addition, structure is significant in the specification without tax incentives and with ETRINCENT. This could indicate that constraints making it harder to change laws lead to more stable rules, which in turn, have a positive impact on the investment climate (see e.g., Edmiston, 2004, Hanlon et al. 2017 for support for this).

Table 4. Gross Fixed Capital Formation and Aggregate Tax Incentives

\begin{tabular}{|c|c|c|c|c|}
\hline & GFCF & GFCF & GFCF & GFCF \\
\hline Statutory tax rate & $\begin{array}{l}-0.0195 \\
(0.705)\end{array}$ & $\begin{array}{c}0.528 \\
(0.989)\end{array}$ & $\begin{array}{l}-0.143 \\
(0.711)\end{array}$ & $\begin{array}{c}0.271 \\
(0.595)\end{array}$ \\
\hline REVINCENT & & $\begin{array}{l}-0.252 \\
(0.791)\end{array}$ & & \\
\hline ETRINCENT & & & $\begin{array}{c}0.373 \\
(0.324)\end{array}$ & \\
\hline HANDINCENT & & & & $\begin{array}{c}-0.00278 \\
(0.00439)\end{array}$ \\
\hline GDP per capita & $\begin{array}{c}1.818 * * * \\
(0.612)\end{array}$ & $\begin{array}{c}0.835 \\
(0.505)\end{array}$ & $\begin{array}{c}1.767 * * \\
(0.620)\end{array}$ & $\begin{array}{c}1.567 * * \\
(0.619)\end{array}$ \\
\hline Rel real world & 0.00751 & 0.00829 & 0.00796 & 0.0122 \\
\hline Growth & $(0.0113)$ & $(0.0101)$ & $(0.0112)$ & $(0.0140)$ \\
\hline Trade & $\begin{array}{l}-0.00584 * \\
(0.00308)\end{array}$ & $\begin{array}{c}-0.00684^{* *} * \\
(0.00288)\end{array}$ & $\begin{array}{l}-0.00615^{*} \\
(0.00316)\end{array}$ & $\begin{array}{c}-0.00364 \\
(0.00291)\end{array}$ \\
\hline Debt/GDP & $\begin{array}{l}-0.000231 \\
(0.000143)\end{array}$ & $\begin{array}{c}-0.000256^{*} \\
(0.000144)\end{array}$ & $\begin{array}{l}-0.000227 \\
(0.000145)\end{array}$ & $\begin{array}{l}-4.66 \mathrm{e}-05 \\
(9.08 \mathrm{e}-05)\end{array}$ \\
\hline Deficit & $\begin{array}{c}0.0168 \\
(0.0111)\end{array}$ & $\begin{array}{l}0.00815 \\
(0.0118)\end{array}$ & $\begin{array}{c}0.0172 \\
(0.0112)\end{array}$ & $\begin{array}{c}0.0218 \\
(0.0143)\end{array}$ \\
\hline Gov't size & $\begin{array}{r}-0.00977 \\
(0.0128)\end{array}$ & $\begin{array}{c}-0.0154 \\
(0.00945)\end{array}$ & $\begin{array}{c}-0.00938 \\
(0.0124)\end{array}$ & $\begin{array}{l}0.00455 \\
(0.0162)\end{array}$ \\
\hline Interest rate & $\begin{array}{c}-0.0117 \\
(0.0194)\end{array}$ & $\begin{array}{c}-0.00837 \\
(0.0267)\end{array}$ & $\begin{array}{c}-0.00917 \\
(0.0200)\end{array}$ & $\begin{array}{c}-0.0292 * \\
(0.0147)\end{array}$ \\
\hline Index econ freedom & $\begin{array}{l}0.0104 * * \\
(0.00457)\end{array}$ & $\begin{array}{c}0.00758 \\
(0.00456)\end{array}$ & $\begin{array}{l}0.0100 * * \\
(0.00472)\end{array}$ & $\begin{array}{l}0.00952 * \\
(0.00511)\end{array}$ \\
\hline Gov't party & $\begin{array}{c}0.0154 \\
(0.00937)\end{array}$ & $\begin{array}{c}0.00860 \\
(0.00908)\end{array}$ & $\begin{array}{c}0.0145 \\
(0.00854)\end{array}$ & $\begin{array}{c}0.0101 \\
(0.00853)\end{array}$ \\
\hline Fractionalization & $\begin{array}{c}-0.00785^{* *} \\
(0.00326)\end{array}$ & $\begin{array}{l}-0.00611^{*} \\
(0.00311)\end{array}$ & $\begin{array}{c}-0.00768 * * \\
(0.00316)\end{array}$ & $\begin{array}{c}-0.00856 * * * \\
(0.00276)\end{array}$ \\
\hline $\begin{array}{l}\text { Institutional } \\
\text { Constraint }\end{array}$ & $\begin{array}{c}-0.0326 \\
(0.0642)\end{array}$ & $\begin{array}{c}-0.0200 \\
(0.0482)\end{array}$ & $\begin{array}{c}-0.0297 \\
(0.0629)\end{array}$ & $\begin{array}{l}0.00834 \\
(0.0602)\end{array}$ \\
\hline Stucture & $\begin{array}{c}0.0825 \\
(0.0862)\end{array}$ & $\begin{array}{c}0.0516 \\
(0.0482)\end{array}$ & $\begin{array}{c}0.0541 \\
(0.0894)\end{array}$ & $\begin{array}{c}0.0639 \\
(0.0601)\end{array}$ \\
\hline Constant & $\begin{array}{l}-6.049 \\
(6.632)\end{array}$ & $\begin{array}{c}4.609 \\
(5.300)\end{array}$ & $\begin{array}{c}-5.480 \\
(6.781)\end{array}$ & $\begin{array}{l}-4.410 \\
(7.007)\end{array}$ \\
\hline Observations & 227 & 206 & 227 & 190 \\
\hline R-squared & 0.921 & 0.929 & 0.922 & 0.938 \\
\hline Number of code & 20 & 18 & 20 & 17 \\
\hline
\end{tabular}

Robust standard errors in parentheses

$* * * \mathrm{p}<0.01, * * \mathrm{p}<0.05, * \mathrm{p}<0.1$ 
Table 5. Gross Fixed Capital Formation and Individual Tax Incentives

\begin{tabular}{|c|c|c|c|c|c|c|c|}
\hline & GFCF & GFCF & GFCF & GFCF & GFCF & GFCF & GFCF \\
\hline Statutory tax rate & $\begin{array}{c}0.430 \\
(0.555)\end{array}$ & $\begin{array}{c}0.271 \\
(0.593)\end{array}$ & $\begin{array}{c}0.354 \\
(0.571)\end{array}$ & $\begin{array}{c}0.260 \\
(0.599)\end{array}$ & $\begin{array}{c}0.317 \\
(0.582)\end{array}$ & $\begin{array}{c}0.288 \\
(0.590)\end{array}$ & $\begin{array}{l}0.290 \\
(0.605)\end{array}$ \\
\hline Depriciation & $\begin{array}{l}-0.125^{* *} \\
(0.0518)\end{array}$ & & & & & & \\
\hline Loss rules & & $\begin{array}{c}0.0462 \\
(0.0272)\end{array}$ & & & & & \\
\hline Tax treaties & & & $\begin{array}{c}0.00276 \\
(0.00255)\end{array}$ & & & & \\
\hline Investment tax credit & & & & $\begin{array}{l}-0.0177 \\
(0.0404)\end{array}$ & & & \\
\hline $\mathrm{R} \& \mathrm{D}$ & & & & & $\begin{array}{l}-0.0252 \\
(0.0398)\end{array}$ & & \\
\hline $\begin{array}{l}\text { Entreprise } \\
\text { Zone }\end{array}$ & & & & & & $\begin{array}{l}-0.0268 \\
(0.0468)\end{array}$ & \\
\hline $\begin{array}{l}\text { New and small } \\
\text { Firm }\end{array}$ & & & & & & & $\begin{array}{l}-0.0129 \\
(0.0345)\end{array}$ \\
\hline GDP per capita & $\begin{array}{l}1.436 * * \\
(0.605)\end{array}$ & $\begin{array}{l}1.640 * * \\
(0.652)\end{array}$ & $\begin{array}{l}1.585^{* *} \\
(0.654)\end{array}$ & $\begin{array}{l}1.547 * * \\
(0.621)\end{array}$ & $\begin{array}{l}1.595^{* *} \\
(0.643)\end{array}$ & $\begin{array}{l}1.562 * * \\
(0.685)\end{array}$ & $\begin{array}{l}1.615^{* * *} \\
(0.652)\end{array}$ \\
\hline Rel real world & 0.0156 & 0.0104 & 0.0145 & 0.0122 & 0.0118 & 0.0129 & 0.0110 \\
\hline $\begin{array}{l}\text { Growth } \\
\text { Trade }\end{array}$ & $\begin{array}{l}(0.0132) \\
-0.00435 \\
(0.00297)\end{array}$ & $\begin{array}{l}(0.0134) \\
-0.00321 \\
(0.00300)\end{array}$ & $\begin{array}{l}(0.0130) \\
-0.00387 \\
(0.00293)\end{array}$ & $\begin{array}{l}(0.0141) \\
-0.00341 \\
(0.00293)\end{array}$ & $\begin{array}{l}(0.0138) \\
-0.00334 \\
(0.00291)\end{array}$ & $\begin{array}{l}(0.0136) \\
-0.00335 \\
(0.00293)\end{array}$ & $\begin{array}{l}(0.0136) \\
-0.00330 \\
(0.00290)\end{array}$ \\
\hline Debt/GDP & $\begin{array}{c}-7.05 e-05 \\
(0.000100)\end{array}$ & $\begin{array}{l}-5.95 e-05 \\
(9.13 e-05)\end{array}$ & $\begin{array}{l}-2.69 \mathrm{e}-05 \\
(8.64 \mathrm{e}-05)\end{array}$ & $\begin{array}{l}-3.63 e-05 \\
(9.08 \mathrm{e}-05)\end{array}$ & $\begin{array}{l}-5.29 \mathrm{e}-05 \\
(8.46 \mathrm{e}-05)\end{array}$ & $\begin{array}{l}-2.84 \mathrm{e}-05 \\
(8.21 \mathrm{e}-05)\end{array}$ & $\begin{array}{l}-4.40 \mathrm{e}-05 \\
(8.87 \mathrm{e}-05)\end{array}$ \\
\hline Deficit & $\begin{array}{c}0.0237 \\
(0.0139)\end{array}$ & $\begin{array}{c}0.0199 \\
(0.0142)\end{array}$ & $\begin{array}{c}0.0213 \\
(0.0141)\end{array}$ & $\begin{array}{c}0.0211 \\
(0.0140)\end{array}$ & $\begin{array}{c}0.0222 \\
(0.0145)\end{array}$ & $\begin{array}{c}0.0221 \\
(0.0147)\end{array}$ & $\begin{array}{c}0.0208 \\
(0.0143)\end{array}$ \\
\hline Gov't size & $\begin{array}{l}0.00774 \\
(0.0142)\end{array}$ & $\begin{array}{l}0.00232 \\
(0.0162)\end{array}$ & $\begin{array}{l}0.00156 \\
(0.0160)\end{array}$ & $\begin{array}{l}0.00351 \\
(0.0163)\end{array}$ & $\begin{array}{l}0.00539 \\
(0.0166)\end{array}$ & $\begin{array}{l}0.00507 \\
(0.0174)\end{array}$ & $\begin{array}{l}0.00309 \\
(0.0167)\end{array}$ \\
\hline Interest rate & $\begin{array}{l}-0.0292 * \\
(0.0140)\end{array}$ & $\begin{array}{c}-0.0311^{* *} \\
(0.0139)\end{array}$ & $\begin{array}{c}-0.0330 * * \\
(0.0143)\end{array}$ & $\begin{array}{c}-0.0302 * * \\
(0.0140)\end{array}$ & $\begin{array}{l}-0.0303^{*} \\
(0.0154)\end{array}$ & $\begin{array}{l}-0.0333^{*} \\
(0.0162)\end{array}$ & $\begin{array}{l}-0.0305^{*} \\
(0.0147)\end{array}$ \\
\hline Index econ freedom & $\begin{array}{c}0.00817 \\
(0.00541)\end{array}$ & $\begin{array}{c}0.00758 \\
(0.00557)\end{array}$ & $\begin{array}{l}0.00958^{*} \\
(0.00533)\end{array}$ & $\begin{array}{l}0.00926^{*} \\
(0.00497)\end{array}$ & $\begin{array}{l}0.00934 * \\
(0.00529)\end{array}$ & $\begin{array}{c}0.00833 \\
(0.00555)\end{array}$ & $\begin{array}{l}0.00988^{*} \\
(0.00543)\end{array}$ \\
\hline Gov't party & $\begin{array}{c}0.00880 \\
(0.00829)\end{array}$ & $\begin{array}{c}0.0129 \\
(0.00833)\end{array}$ & $\begin{array}{c}0.00859 \\
(0.00791)\end{array}$ & $\begin{array}{c}0.0104 \\
(0.00862)\end{array}$ & $\begin{array}{c}0.00967 \\
(0.00839)\end{array}$ & $\begin{array}{c}0.00974 \\
(0.00772) \\
-\end{array}$ & $\begin{array}{c}0.0112 \\
(0.00851) \\
-\end{array}$ \\
\hline Fractionalization & $\begin{array}{c}-0.00665 * * \\
(0.00272)\end{array}$ & $\begin{array}{c}-0.00824 * * \\
(0.00308)\end{array}$ & $\begin{array}{c}-0.00806 * * * \\
(0.00224)\end{array}$ & $\begin{array}{c}-0.00869 * * \\
(0.00301)\end{array}$ & $\begin{array}{c}-0.00855 * * \\
(0.00302)\end{array}$ & $\begin{array}{c}0.00867 * * * \\
(0.00293)\end{array}$ & $\begin{array}{c}0.00910 * * * \\
(0.00279)\end{array}$ \\
\hline $\begin{array}{l}\text { Institutional } \\
\text { Constraint }\end{array}$ & $\begin{array}{c}0.0232 \\
(0.0567)\end{array}$ & $\begin{array}{c}0.0203 \\
(0.0604)\end{array}$ & $\begin{array}{c}0.0132 \\
(0.0599)\end{array}$ & $\begin{array}{l}0.00746 \\
(0.0580)\end{array}$ & $\begin{array}{c}0.0145 \\
(0.0597)\end{array}$ & $\begin{array}{c}0.0167 \\
(0.0626)\end{array}$ & $\begin{array}{c}0.0123 \\
(0.0612)\end{array}$ \\
\hline Structure & $\begin{array}{c}0.0559 \\
(0.0536)\end{array}$ & $\begin{array}{c}0.0511 \\
(0.0607)\end{array}$ & $\begin{array}{c}0.0405 \\
(0.0577)\end{array}$ & $\begin{array}{c}0.0584 \\
(0.0605)\end{array}$ & $\begin{array}{c}0.0628 \\
(0.0617)\end{array}$ & $\begin{array}{c}0.0688 \\
(0.0611)\end{array}$ & $\begin{array}{c}0.0618 \\
(0.0571)\end{array}$ \\
\hline Constant & $\begin{array}{l}-3.170 \\
(6.792)\end{array}$ & $\begin{array}{c}-5.105 \\
(7.360)\end{array}$ & $\begin{array}{l}-4.706 \\
(7.357)\end{array}$ & $\begin{array}{c}-4.145 \\
(7.000)\end{array}$ & $\begin{array}{c}-4.794 \\
(7.323)\end{array}$ & $\begin{array}{c}-4.359 \\
(7.637)\end{array}$ & $\begin{array}{c}-4.884 \\
(7.375)\end{array}$ \\
\hline Observations & 190 & 190 & 190 & 190 & 190 & 190 & 190 \\
\hline R-squared & 0.942 & 0.939 & 0.939 & 0.938 & 0.938 & 0.939 & 0.938 \\
\hline Number of code & 17 & 17 & 17 & 17 & 17 & 17 & 17 \\
\hline
\end{tabular}

Robust standard errors in parentheses $* * * \mathrm{p}<0.01, * * \mathrm{p}<0.05, * \mathrm{p}<0.1$

We now turn to the individual hand-collected incentives and their impact on FDI inflows, presented in table 3. The statutory tax rate remains negative and with semi-elasticities in line with previous results. Most of the individual tax incentives have no impact on FDI. The only tax incentive that appears to have a positive effect on FDI are tax treaties. Tax treaties measure the number of tax treaties in force. Tax treaties reduce uncertainty, and again suggest that uncertainty reduces investments. The positive and significant correlation, although only at 10 percent, for incentives for small and new firms is perhaps more surprising. All the other tax incentives; depreciation rules, loss rules, investment credits, enterprise zones, and incentives for $R \& D$ are found to be uncorrelated with FDI inflows. 
Taxes and tax incentives may have different impacts on gross fixed capital formation than on FDI flows. Table 4presents the results for aggregate tax incentives and gross fixed capital formation. Neither statutory tax rates nor our aggregate tax incentives seem to correlate with GFCF. Instead, GDP per capita and economic freedom correlates with GFCF. Among the political variables, fractionalization seems to influence GFCF negatively. The fractionalization measure differs from institutional constraint and structure, the other two measures of political stability, in that the latter are more institutionally determined and less affected by internal and current domestic political situations. It may, hence, not be surprising that fractionalization matters more for the overall capital measure, and that the other two political measures are more important for foreign capital flows. Finally, table 5 presents the results for the individual tax incentives and GFCF. As for FDI inflows, tax incentives appear to be uncorrelated with capital formation. The only incentive that is weakly correlated is depreciation rules, and with a negative sign suggesting more generous depreciation rules correlates negatively with GFCF.

\section{Conclusions}

In this paper we have analyzed various tax incentives and factors determining them, and their effect on FDI inflows and gross fixed capital formation. It is not straightforward how to measure tax incentives, and all measures suffer from weaknesses. We use three different measures; one broad measure based on the difference between the taxes that should have been paid if all profits where taxed at the statutory tax rate and actual tax revenues obtained, one based on the differences between the statutory and the effective tax rate, and finally one based on an index counting the number of tax incentives offered.

We do find support indicating that politically constrained countries offer tax incentives as an alternative to lower statutory corporate tax rates. We also find that for our preferred tax incentive measure, tax incentives seem to be used to compensate for high statutory tax rates rather than complement low statutory tax rates. However, our results do not give much support to the hypothesis that countries act strategically when it comes to offering tax incentives; they do not seem to be influenced by neighboring countries' tax incentives. This result is in contrast to the strategically behavior found for setting statutory corporate tax rates. We also investigate how effective tax incentives are in boosting FDI inflows and capital formation. Neither offering aggregate nor specific tax incentives seem to be a particular effective method to stimulate FDI or capital formation. Instead, a more effective policy to generate FDI inflows is to lower statutory corporate tax rates. The only tax incentive that seems to have a positive correlation with FDI inflows is the number of tax treaties in force. This together with our political variables suggests that policy and tax uncertainty have a negative impact on the investment climate. Hence, our results indicate that offering tax incentives is a less effective measure to generate investments than lowering statutory tax rates, and that policy and tax uncertainty is negative for the investment climate.

\section{References}

Alstadsaeter, A, Barrios, S., Nicodema G., Skonieczna, A. \&VezzaniA.(2018). Patent boxes design, patent location, and local R\&D. Economic Policy, 33(93), 131-172.

Ashworth, J. \&HeyndelsB.(2001). Political fragmentation and the evolution of national tax structures in the OECD.International Tax and Public Finance, 8, 377-393.

Ashworth, J. \&HeyndelsB. (2002). Tax structure turbulence in OECD countries. Public Choice, 111,347-376.

Atwood, T. J., Drake,M. S, Myers, J. N. \& Myers L. A. (2012). Home Country Tax System Characteristics and Corporate Tax Avoidance: International Evidence.The Accounting Review, 87, \#6, 1831-1860.

Bloom, N, Griffith, R. \& Van Reenen J. (2002). Do R\&D tax credits work? Evidence from a panel of countries, 1979-1997.Journal of Public Economics, 85, 1-31.

Bondonio, D. \&Greenbaum R.T.(2007). Do local tax incentives affect economic growth? What mean impacts miss in the analysis of enterprise zone policies.Regional Studies and Urban Economics, 37, 121-136.

Brueckner, J.K. (2003). Strategic interaction among governments: an overview of empirical studies.International Regional Science Review, 26, 175-188.

Bry B., Perret S., Thomas,A. \& O’Reilly P. (2016). Tax design for inclusive economic growth. OECD Working Papers, No 26, OECD, Paris.

Buchanan, J.M. (2008). Same players, different game: How better rules make better politics. Constitutional Political Economy, 19, 171-179.

Devereux, M.P., Griffith R.\&KlemmA. (2002). Corporate income tax reforms and international tax competition.Economic Policy, 35, 313-344. 
Devereux, M., Lockwood B.\&Redoano M. (2006). Horizontal and vertical indirect tax competition:Theory and some evidence from the USA. Journal of Public Economics, 91, 451-479.

Devereux, M., Lockwood B. \&Redoana M.(2008). Do countries compete over corporate tax rate? Journal of Public Economics, 92, 1210-1235.

Economic Freedom of the World Index published by the Economic Freedom Index. Annual databases are available at www.freetheworld.com

Edminston, K. (2004). Tax uncertainty and investment: A cross-country empirical examination.Economic Inquiry, 42(3), 424-440.

Ghinamo, M.,Panteghini P.\&Revelli F.(2007). FDI determination and corporate tax competition in avolatile world. Cesifo working paper \#1965.

Gugl, E \&Zodrow G.R. (2006). International tax competition and tax incentives in developing countries. inAlm, J, Martinez-Vazquez \& Rider M. (eds).The challenge of tax reform in a global economy (pp 167-191). Berlin, Springer.

Hanlon, M. E.,Maydew L.\&Saavedra, D. (2017).The taxman cometh: Does tax uncertainty affect corporate cash holdings.Review of Accounting Studies, 22(3), 1198-1228.

Hansson, $\AA$ \& Brokelind C. (2014).Tax incentive, tax expenditures theories in R\&D: the case of Sweden. World Tax Journal, 6(2), 168-200.

Hansson Å., Porter S.\& Williams S.P. (2015).The importance of the political process on corporate tax policy.Constitutional Political Economy, 23(3), 281-306.

Heinemann, F. M., Veresch O.\&Rincke J. (2010). Rate-cutting tax reforms and corporatecompetition in Europe.Economics and Politics, 22, 498-518.

James, S. (2009). "Incentives and Investments: Evidence and Policy Implication. World Bank working paper.

Janeba, E. \& Peters W. (1999). Tax evasion, tax competition and the gains from non-discrimination: The case of interest taxation in Europe.Economic Journal, 109, 93-101.

Janeba, E. \& Smart M. (2003). Is targeted tax competition less harmful than its remedies? International Tax and Public Finance, 10, 259-280.

Jensen, N.M. (2013). Domestic Institutions and the taxing of multinational corporations. International Studies Quarterly, 57, 751-759.

Kawano, L.\&Slemrod, J. (2012). The Effects of Tax Rates and Tax Base on Corporate Tax Revenue.working paper.

Keen, M. (2001). Preferential regimes can make tax competition less harmful.National Tax Journal, 54, 757-762.

Klemm, A. (2010). Causes, benefits, and risks of business tax incentives.International Tax and Public Finance, 17, 315-336.

Klemm, A. \& Van Parys S.(2012).Empirical Evidence on the effects of tax incentives.International Tax and Public Finance, 19, 393-423.

Lee, N. \& Swenson C. (2012). Are multinational corporate tax rules as important as tax taxes? International Journal of Accounting, 47, 155-167.

LeSage J. \& Pace R. (2009). Introduction to spatial econometrics. Boca Raton, FL: Chapman and Hall.

Mendoza, E., Razin, A.\&Tesar L. (1994). Effective tax rates in macroeconomics Cross-country estimates of tax rates on factor incomes and consumption. Journal of Monetary Economics, 34,297-323.

OECD. (2001).Corporate tax incentives for foreign direct investment. OECD Tax Policy Study No. 4.

Rae, D. (1968). A note on the fractionalization of some European party systems. Comparative Political Studies, I, 413-418.

Schmidt, M. G. (1996). When parties matter: A review of the possibilities and limits of partisan influence on public policy. European Journal of Political Research, 30, 155-183.

Slemrod, J. (2004). Are corporate tax rates, or countries, converging? Journal of Public Economics, 88(6), 11691186.

Van Parys, S. (2012). The effectiveness of tax incentives in attracting investment: Evidence from Developing Countries.Reflets et Perspectives de la Vie Economique (Tome LI), 129-141.

Wilson, J.D. (1999). Theories of tax competition.National Tax Journal, 52(2), 269-304.

Wilson J.D. \&Wildasin D. (2004). Tax competition: bane or boon. Journal of Public Economics, 88, 1065-1091.

Wildasin, D. (1998). Nash equilibria in models of fiscal competition. Journal of Public Economics, 35, 229-240. 